\title{
Profile analysis and factors influencing the adoption of pulses production practices of farmers in Andhra Pradesh - baseline study under biotech Kisan hub project
}

\author{
T. Srinivas, T. Venkata Sridhar*, P. Punna Rao ${ }^{1}$, K.S. Purnima ${ }^{1}$, E. Chandraidu ${ }^{2}$ and G. Prasad Babu ${ }^{3}$ \\ Department of Acadmic and Education, Administrative Office, Acharya N.G. Ranga \\ Agricultural University, Lam Guntur (A.P.) India \\ (Email: sridhar.thammineni@gmail.com; thumati28@gmail.com)
}

\begin{abstract}
Biotech-Kisan hub has been established at Acharya N.G. Ranga Agricultural University, Guntur, Andhra Pradesh with the major objectives of assessment of the yield gaps in major pulses and groundnut grown in scarce rainfall and north coastal zones. As part of the project, a base line survey was conducted at selected 25 villages of Srikakulam, Visakhapatnam, Anantapur and Kurnool districts to assess the potentials of the districts by developing a database in order to exploit resources and develop action plans in co-operation with line departments. Sixty farmers from each district were randomly selected to obtain baseline information making the total sample size is 240 farmers cultivating the targeted pulse crops in the district. A pre-tested interview schedule was used to collect data from the respondents. A profile analysis was done and revealed that the North coastal zone showed Low scores in Knowledge, Risk orientation and Mass media participation and medium in Innovativeness, Social participation and Extension contact, while the Scarce rainfall zone showed medium in all the variables except for Risk orientation. The findings also revealed that the Adoption index was found to be medium to low in case of Srikakulam and Visakhapatnam districts and Medium to High in case of Ananthpur and Kurnool districts indicating that more focused interventions are required in the North coastal zone when compared to Scarce rainfall zone. The overall adoption index indicated in Table 3 showed that majority of the respondents fell in the medium category (49.00\%) followed by High $(35.00 \%)$ and low category $(15.00 \%)$ indicating that there is scope to increase adoption of recommended practices. The chi square test of profile characteristics and adoption indicated that all the six independent variables- Knowledge, Innovativeness, Risk orientation, Mass media participation, Social participation and Extension contact are significantly influencing the adoption levels of farmers in the four districts.
\end{abstract}

Key Words : Biotech hub, Agroclimatic zones, Recommended practices

View Point Article : Srinivas, T., Venkata Sridhar, T., Punna Rao, P., Purnima, K.S., Chandraidu, E. and Prasad Babu, G. (2021). Profile analysis and factors influencing the adoption of pulses production practices of farmers in Andhra Pradesh - baseline study under biotech Kisan Hub Project. Internat. J. agric. Sci., 17 (1) : 32-35, DOI:10.15740/HAS/IJAS/17.1/32-35. Copyright@2021: Hind Agri-Horticultural Society.

Article History : Received : 09.06.2020; Revised : 09.11.2020; Accepted : 10.12.2020

\footnotetext{
* Author for correspondence (Present Address) : Biotech KISAN Hub, Administrative Office, ANGRAU, Lam, Guntur (A.P.) India ${ }^{1}$ Acharya N.G. Ranga Agricultural University, Lam Guntur (A.P.) India

${ }^{2}$ Krishi Vigyan Kendra, Kondempudi (A.P.) India

${ }^{3}$ Krishi Vigyan Kendra, Banavasi (A.P.) India
} 